Original Article

\title{
Pengaruh Pendampingan Terhadap Pengetahuan dan Keterampilan Kader Posyandu dalam Deteksi Dini Stunting
}

\author{
The Effect of Assistance on Knowledge and Skills of Posyandu Cadres in Early Detection of \\ Stunting
}

\author{
Sony Bernike Magdalena Sitorus*1, Ni Made Ridla Nilasanti Parwata ${ }^{2}$, Fransisca Noya ${ }^{1}$ \\ ${ }^{1}$ Prodi D-III Kebidanan Poso, Poltekkes Kemenkes Palu \\ ${ }^{2}$ Prodi D-III Keperawatan Poso, Poltekkes Kemenkes Palu \\ (bernike.libra@gmail.com,085275733700)
}

\begin{abstract}
ABSTRAK
Tujuan penelitian ini adalah untuk menganalisis pengaruh pendampingan terhadap pengetahuan dan keterampilan kader dalam deteksi dini stunting pada baduta di Wilayah Kerja Puskesmas Malei Kecamatan Lage. Jenis penelitian ini adalah quasi experimen dengan menggunakan desain penelitian pre-eksperiment one group pretest-posttest. Populasi pada penelitian ini adalah seluruh kader posyandu balita yang tercatat di Wilayah kerja Puskesmas Malei Kecamatan Lage. Sampel pada penelitian ini sebanyak 30 kader, teknik pengambilan sampel dengan cara simpel random sampling. Hasil uji normalitas diperoleh data tidak berdistribusi normal, uji hipotesis menggunakan uji Wilcoxon. Hasil penelitian menunjukkan bahwa adanya peningkatan rerata skor pengetahuan kader sebelum diberikan pendampingan adalah $32,80(\mathrm{SD}=9,768)$, setelah diberikan pendampingan rerata skor pengetahuan adalah $87,10(\mathrm{SD}=5,677)$ dan rerata skor tindakan kader sebelum pendampingan $25,83(\mathrm{SD}=19,122)$, setelah dilakukan pendampingan berupa penyuluhan, demostrasi dan praktikum kepada kader rata-rata skor tindakan meningkat menjadi 79,17 ( $\mathrm{SD}=9,476)$. Pada hasil uji statistik terdapat perbedaan secara bermakna sebelum dan sesudah diberikan intervensi dengan nilai $0,000,(p<0,05)$. Hal ini menunjukkan terdapat pengaruh pendampingan terhadap pengetahuan dan tindakan kader dalam deteksi dini stunting.
\end{abstract}

Kata kunci : Pendampingan Kader, Deteksi Dini, Stunting

\section{ABSTRACT}

The purpose of this study was to analyze the effect of mentoring on the knowledge and skills of cadres in early detection of stunting in children under two in the Malei Public Health Center, Lage District. This type of research is a quasi-experimental research design using a pre-experimental one group pretest-posttest. The population in this study were all cadres of Posyandu under five who were recorded in the working area of the Malei Health Center, Lage District. The sample in this study were 30 cadres, the sampling technique was simple random sampling. The results of the normality test obtained that the data were not normally distributed, the hypothesis was tested using the Wilcoxon test. The results showed that there was an increase in the mean score of knowledge of cadres before being given assistance was 32.80 ( $S D=9.768)$, after being given mentoring the average score of knowledge was $87.10(S D=5,677)$ and the mean score of cadre actions before mentoring was $25.83(S D) .=19.122)$, after providing assistance in the form of counseling, demonstration and practicum to cadres, the average score of actions increased to 79.17 ( $S D=9.476)$. In the statistical test results, there was a significant difference before and after the intervention with a value of $0.000,(p<0.05)$. This shows that there is an influence of mentoring on the knowledge and actions of cadres in early detection of stunting.

Keywords: Cadre Assistance, Early Detection, stunting

https://doi.org/10.33860/jik.v15i3.459

(C) 2021 by the authors. Submitted for possible open access publication under the terms and conditions of the Creative Commons Attribution (CC BY SA) license (https://creativecommons.org/licenses/by-sa/4.0/). 


\section{PENDAHULUAN}

Target capaian menurunkan Angka Kematian Balita (AKABA) 25 per 1000 kelahiran hidup di tahun 2030 merupakan salah satu tujuan dari Pembangunan berkelanjutan atau Sustainabel Development Goals (SDGs). Hal ini dapat dicapai, apabila kesehatan balita sangat diperhatikan maka balita dapat terhindar dari masalah gizi buruk dan resiko kematian ${ }^{1}$.

Pertumbuhan dan perkembangan yang optimal dapat terjadi jika bayi dan anak diberikan makanan yang tepat. Apabila bayi dan anak tidak mengkonsumsi makanan yang beraneka ragam dengan frekuensi makan yang cukup, maka asupan gizinya tidak akan terpenuhi sehingga dapat mengalami gizi kurang yang dapat menyebabkan anak pendek (stunting) ${ }^{2}$.

Pada tahun 2017 data WHO, Indosesia menduduki peringkat ketiga dimana angka prevalensi stunting paling tinggi di Asia yaitu 36,4\%. Angka kejadian Stunting di Indonesia telah terjadi penurunan dari tahun 2013 sampai 2018 yaitu dari $37,2 \%$ menjadi $30,8 \%$. Penurunan angka stunting di Indonesia merupakan pencapaian yang baik, Tetapi pencapaian ini belum sesuai dengan standar WHO, dimana batasan maksimal adalah 20\% atau seperlima dari total anak balita ${ }^{3}$. Ini artinya pertumbuhan yang dialami sekitar 8,9 juta anak di Indonesia tidak maksimal, atau dengan kata lain satu dari tiga anak mengalami stunting. Anak yang tingginya di bawah rata-rata yaitu sekitar lebih dari sepertiga anak yang berada pada usia di bawah 5 tahun ${ }^{4}$.

Stunting merupakan salah satu masalah kesehatan masyarakat yang berkaitan dengan meningkatnya risiko terjadinya hambatan pada pertumbuhan motorik dan mental. Stunting terjadi apabila catcth up growth dan growth faltering tidak terpenuhi yang menggambarkan ketidakmampuan dalam mencapai pertumbuhan yang optimal. Kesimpulannya adalah balita yang lahir dimana memiliki berat badan lahir normal apabila pemenuhan kebutuhan berikutnya tidak dapat dipenuhi dengan baik maka dapat mengalami stunting (Kemenkes 2013).

Anak balita dengan permasalahan gizi ini erat hubungannya dengan pemantauan pertumbuhan yang kurang optimal pada anak, hal ini dapat lihat dari keikutsertaan masyarakat yang tergolong rendah dan keterampilan kader yang masih kurang baik. Kader posyandu merupakan bagian dari bagian masyarakat yang dipilih untuk bekerja sukarela untuk melakukankan kegiatan terkait pelayanan kesehatan yang sederhana pada pelaksanaan posyandu. Menurut Kemenkes RI salah satu dari tiga kriteria kader posyandu yaitu kader yang ditunjuk adalah diprioritaskan bagian dari masyarakat setempat. Sehingga kader lebih mudah melaksanakan tugasnya dalam memantau situasi dan kondisi bayi dan balita yang ada di wilayah kerja posyandu dan tugas kader yaitu melakukan kunjungan rumah untuk memantau pertumbuhan bagi bayi dan balita ${ }^{5}$.

Untuk dapat melaksanakan tugasnya tersebut, maka sangat penting memberikan pendampingan bagi kader melalui penyuluhan, diskusi, dan praktek pengukuran panjang badan serta pengisian grafik KMS.

Tujuan dari pendampingan dengan metode ini adalah mendorong para kader untuk berpikir secara kritis, mau memberikan tanggapan dan pertanyaan secara leluasa, menyumbangkan pemikirannya untuk memecahkan masalah bersama serta mengambil satu atau beberapa alteratif jawaban untuk pemecahan masalah dengan pertimbangan yang cermat ${ }^{6}$. Berdasarkan kenyataan tersebut dibutuhkan suatu tinjauan seperti model intervensi dimana bertujuan membantu dalam percepatan penanganan masalah gizi terutama stunting pada baduta.

Tujuan penelitian ini adalah untuk menganalisa bagaimana pengetahuan dan keterampilan kader posyandu sebelum dan sesudah diberikan intervensi berupa pendampingan pemantauan pertumbuhan baduta dalam deteksi dini stunting.

\section{METODE PENELITIAN}

Jenis penelitian ini adalah quasy eksperiment. Desain yang digunakan dalam penelitian ini adalah pre-eksperiment one group pretest-posttest. Desain ini membuat satu kelompok yang diberikan pre-test (O), kemudian diberikan perlakuan (X) dan terakhir dilakukan post-test. Intervensi dikatakan 
berhasil dengan cara membandingkan nilai pretest dan nilai post-test. Pada penelitian ini dilakukan di Wilayah kerja Puskesmas Malei Kecamatan Lage Kabupaten Poso pada tanggal 28 September sampai tanggal 31 Oktober 2020.

Populasi pada penelitian ini adalah seluruh kader posyandu yang tercatat di Wilayah kerja Puskesmas Malei Kecamatan Lage berjumlah 32 orang. Sampel merupakan bagian dari populasi diambil dari keseluruhan objek penelitian dengan menggunakan rumus slovin berjumlah 30 orang. Teknik pengambilan sampel menggunakan sampel acak sederhana (simpel random sampling). Teknik pengumpulan data dalam penelitian ini menggunakan data primer yaitu dengan cara melakukan wawancara dengan menggunakan kuesioner dan observasi, data sekunder yaitu dengan catatan-catatan atau dokumentasi datadata yang sudah tersedia yang diambil dari Puskesmas Malei. Hasil dari penelitian ini disajikan dalam bentuk tabel distribusi frekuensi dan narasi.

Pada penelitian ini proses pendampingan yang diberikan pada para kader posyandu yaitu melalui penyuluhan (ceramah) dan diskusi, melalukan demonstrasi, simulasi serta praktikum dalam mengukuran antropometri dan pengisian grafik pertumbuhan untuk menentukan status gizi baduta.

Analisis data yang digunakan adalah analisis univariat yaitu untuk memperoleh gambaran pada masing-masing variabel independen dan analisis bivariat yaitu untuk mengetahui hubungan dua variabel dengan menggunakan uji statistik. Hasil uji normalitas Shapiro-Wilk diperoleh data tidak berdistribusi normal maka uji statistik yang digunakan yaitu uji Wilcoxon.

\section{HASIL}

Berdasarkan karakteristik kader pada tabel di atas, mayoritas kader berumur $>35$ Tahun sebanyak 22 responden (73,3\%), paling banyak kader berpendidikan SMA sebanyak 14 reponden $(46,7)$ dan mayoritas lama kerja kader $>10$ Tahun sebanyak 15 responden (50\%) (Tabel 1). Pada tabel 2 diketahui bahwa rerata nilai pengetahuan kader kesehatan sebelum dilakukan pendampingan adalah $32,80(\mathrm{SD}=$
9,768), dan rerata nilai pengetahuan kader posyandu setelah dilakukan pendampingan adalah 87,10 $(\mathrm{SD}=5,677)$ dengan rerata peningkatan skor 54,3. Hasil uji statistik menunjukkan adanya peningkatan pada rerata nilai pengetahuan responden setelah diberikan intervensi berupa pendampingan kader posyandu dengan nilai $p=0,000$ berarti $p<0.05$.

Tabel 1. Distribusi Frekuensi Karakteristik Kader Berdasarkan Umur, Pendidikan, Lama kerja

\begin{tabular}{lcc}
\multicolumn{1}{c}{ Karakteristik } & $\begin{array}{c}\text { Frekuensi } \\
(\mathbf{n}=\mathbf{3 0})\end{array}$ & $\mathbf{\%}$ \\
\hline Umur & & \\
$<20-35$ Tahun & 8 & 26,7 \\
$>35$ Tahun & 22 & 73,3 \\
\hline Pendidikan & & \\
SD & 3 & 10 \\
SMP & 13 & 43,3 \\
SMA & 14 & 46,7 \\
\hline Lama Kerja & & \\
1-5 Tahun & 11 & 36,7 \\
$>$ 5-10 Tahun & 4 & 13,3 \\
$>$ 10 Tahun & 15 & 50 \\
\hline
\end{tabular}

Tabel 2. Distribusi Frekuensi Pengetahuan Responden dalam Deteksi Dini dan Pencegahan Stunting pada Baduta Sebelum dan Sesudah Intervensi Pendampingan

\begin{tabular}{|c|c|c|}
\hline $\begin{array}{c}\text { Variabel } \\
\text { Pengetahuan }\end{array}$ & Mean (SD) & $\begin{array}{l}\text { Asymp Sig. } \\
\text { (2-tailed) }\end{array}$ \\
\hline Sebelum & 32,80 & \multirow{4}{*}{0,000} \\
\hline Pendampingan & $(9,768)$ & \\
\hline Sesudah & 87,10 & \\
\hline Pendampingan & $(5,677)$ & \\
\hline
\end{tabular}

Tabel 3. Distribusi Frekuensi Keterampilam Responden dalam Deteksi Dini dan Pencegahan Stunting pada Baduta Sebelum dan Sesudah Intervensi Pendampingan

\begin{tabular}{lcc}
\hline \multicolumn{1}{c}{$\begin{array}{c}\text { Variabel } \\
\text { Tindakan }\end{array}$} & Mean (SD) & $\begin{array}{c}\text { Asymp Sig. } \\
\text { (2-tailed) }\end{array}$ \\
\hline Sebelum & 25,83 & \\
$\begin{array}{l}\text { Pendampingan } \\
\text { Sesudah }\end{array}$ & $(19,122)$ & 0,000 \\
Pendampingan & $79,17(9,476)$ & \\
\hline \multicolumn{1}{c}{ Tabel 3 } & menunjukkan & bahwa pada
\end{tabular}

keterampilan dalam melakukan pengukuran antropometri baduta untuk deteksi dini stunting pada baduta menunjukkan bahwa rata-rata skor tindakan sebelum pendampingan 25,83 $(19,122)$ dan rata-rata skor tindakan setelah 
diberikan pendampingan 79,17 $(9,476)$. Hasil uji statistik menunjukkan adanya perbedaan bermakna pada skor keterampilan responden sebelum dan setelah pendampingan dengan nilai Asymp Sig. 0,000 berarti nilai $p<0,05$.

\section{PEMBaHASAN}

Hasil penelitian menunjukkan bahwa adanya peningkatan skor pengetahuan dan skor keterampilan kader posyandu sebelum dan setelah dilakukan pendampingan. Hasil uji statistik Wilcoxon didapat $p<0,05$ menunjukkan bahwa pendampingan yang dilakukan kepada kader posyandu berpengaruh terhadap peningkatan pengetahuan dan keterampilan kader posyandu.

Hasil dari wawancara saat melaksanakan tinjauan situasi, pihak Puskesmas Malei mengemukakan bahwa keikutsertaan kader posyandu sudah baik dalam hal mengikuti kegiatan di posyandu. Para kader posyandu kurang terpapar dengan informasi mengenai stunting, hanya sebagian kader yang pernah mendengar dan memiliki sedikit informasi tentang stunting. Hal ini yang mungkin menjadi penyebab masih rendahnya rata-rata skor pengetahuan kader dalam deteksi dini stuntig pada baduta.

Seseorang yang memperoleh informasi dari berbagai-bagai sumber akan mempengaruhi pengetahuannya, sehingga apabila seseorang semakin banyak terpapar informasi maka cenderung memiliki pengetahuan yang lebih luas 7. Dari hasil penelitian tersebut menunjukkan bahwa metode penyuluhan efektif untuk meningkatkan pengetahuan para kader posyandu dan metode demostrasi atau simulasi dan praktikum sangat efektif untuk meningkatkan kemampuan keterampilan atau tindakan kader posyandu dalam melakukan pengukuran antropometri, penghitungan umur baduta dan pengisian grafik pertumbuhan yang ada dalam KMS.

Sejalan dengan penelitian Heni Purnamasari, dkk (2020) menyatakan bahwa adanya perbedaan signifikan $(p<0,05)$ pada pengetahuan, self-efficacy, serta praktik, antara sebelum dan sesudah intervensi ${ }^{8}$. Begitu juga penelitian ${ }^{9}$ menyatakan terdapat perbedaan signifikan antara skor keterampilan saat pretest dan posttest. Rata-rata nilai keterampilan meningkat setelah diberikan pelatihan, sehingga dapat disimpulkan terdapat perbedaan antara keterampilan kader posyandu sebelum dan sesudah pelatihan pengukuran antropometri.

Sesuai dengan teori "SOR" (StimulusOrganisme-Respons) menurut Skinner sebagaimana dikutip dalam buku Notoatmodjo, perilaku adalah respon seseorang atas rangsangan yang diterima dari luar (stimulus) yang terbentuk dalam pengetahuan, sikap, dan tindakan. Perilaku yang terjadi lewat proses pemberian stimulus pada organisme, selanjutnya organisme itu memberikan respon ${ }^{7}$.

Kegiatan ini juga dilakukan metode demonstrasi penghitungan umur baduta, pengukuran antropometri dan pengisian grafik pertumbuhan guna untuk mendeteksi dini stunting pada baduta. Dengan demikian diharapkan sasaran mengetahui dan memahami setiap lanhkah-langkah serta cara melaksanakan deteksi dini stunting pada baduta. Kemudian kader-kader posyandu juga melakukan redemonstrasi cara melakukan pengukuran antropometri pada baduta sesuai dengan apa yang telah di demonstrasikan, bertujuan agar pengetahuan yang tersimpan lebih optimal. Sesuai hasil penelitian yang diungkapkan oleh ${ }^{10}$, mengemukakan bahwa pemahaman kader terjadi peningkatan sebesar $1,45 \%$ dilihat dari hasil pretest dan posttest setelah kader memdapatkan intervensi secara demonstrasi tentang MP-ASI. Sama halnya, ${ }^{11}$, menyatakan bahwa cara ceramah interaktif dan demonstrasi menggunakan peraga berpengaruh untuk meningkatkan pengetahuan serta keterampilan.

Pengetahuan/kognitif adalah domain yang sangat penting untuk membentuk perilaku seseorang (overt behavior) ${ }^{12}$, termasuk dalam hal ini keterampilan kader posyandu dalam melaksanakan deteksi dini stunting pada baduta. Tindakan merupakan sikap yang belum nyata terbentuk dalam perilaku. Demi membentuk sikap menjadi perilaku nyata diperlukan faktor pendukung atau suatu keadaan yang memungkinkan ${ }^{13}$.

Penelitian ini sejalan dengan penelitian Salakory yang menyatakan bahwa pelatihan mampu meningkatkan pengetahuan, sikap dan praktik dalam penyuluhan atau sosialisasi pencegahan HIV/AIDS kepada kader 
dibandingkan dengan pemberian informasi dengan cara ceramah serta pembagian leaflet ${ }^{14}$.

Peran serta kader dalam melakukan deteksi dini stunting dapat terlaksana dan memperoleh hasil yang akurat, sebaiknya terlebih dahulu kader diberikan informasi seputar stunting, mempraktekkan cara melakukan pengukuran antropometri khususnya panjang badan baduta dan pengisian grafik KMS. Temuan dalam penelitian ini dapat memberikan informasi dan edukasi kepada kader bahwa stunting dapat terdeteksi secara dini dengan melakukan pemantauan pertumbuhan baduta khususnya panjang badan baduta setiap bulan. Pada saat melaksanakan penelitian, terdapat keterbatasan penelitian yaitu adanya keterbatasan waktu peneliti, sehingga dalam melakukan penyuluhan dan praktikum untuk aplikasi tindakan dalam deteksi dini stunting, kurang efektif dalam melakukan pengawasan. Hal ini dikarenakan adanya batasan/larangan berkumpul dalam jumlah besar pada masa pandemi Covid-19.

\section{KESIMPULAN DAN SARAN}

Kesimpulan dari penelitian ini adalah adanya pengaruh pendampingan terhadap pengetahuan dan keterampilan kader dalam deteksi dini dan pencegahan stunting yang menunjukkan adanya peningkatan rata-rata nilai pengetahuan dan nilai keterampilan responden sebelum dan sesudah dilakukan pendampingan. Peneliti mengharapkan pihak puskesmas untuk dapat meningkatkan kegiatan pelatihan pemantauan pertumbuhan dalam hal pengukuran antropometri dan pengisian grafik pertumbuhan sehingga kader dapat mendeteksi secara dini stunting pada baduta, melakukan follow up terhadap kemampuan kader melaksanakan pengukuran panjang badan, dan mengadakan rolling tugas kader minimal setiap 3 bulan, sehingga setiap kader memiliki kesempatan untuk melakukan pengukuran panjang/tinggi badan.

\section{UCAPAN TERIMAKASIH}

Peneliti mengucapkan terima kasih kepada Kepala Poltekkes Kemenkes Palu yang telah mendukung ketersediaan dana dalam proses penelitian ini, Puskesmas Malei dan Bidan Koordinator, yang telah mengizinkan dan membantu dalam proses penelitian ini.

\section{DAFTAR PUSTAKA}

1. Badan Pusat Statistik. Potret Awal Tujuan Pembangunan Berkelanjutan (Sustainable Development Goals) di Indonesia. Katalog BPS. 2016. 113 p.

2. Survei Demografi dan Kesehatan Indonesia. 2017.

3. Adistie F, Lumbantobing VBM, Maryam NNA. Pemberdayaan Kader Kesehatan Dalam Deteksi Dini Stunting dan Stimulasi Tumbuh Kembang pada Balita. Media Karya Kesehatan. 2018;1(2):173-84.

4. Sandjojo E putro. Buku Saku Desa Dalam Penanganan Stunting. 2017. 42 p.

5. Kementerian Kesehatan RI. Ayo ke POSYANDU. In: Ayo ke POSYANDU. 2017.

6. Nursalam. Konsep Pendidikan Kesehatan. Pendidikan dalam Keperawatan. 2008;

7. Notoatmodjo S. Teori Perilaku. Teori Perilaku. 2007.

8. Purnamasari H, Shaluhiyah Z, Kusumawati A. Pelatihan Kader Posyandu Sebagai Upaya Pencegahan Stunting Pada Balita Di Wilayah Kerja Puskesmas Margadana Dan Puskesmas Tegal Selatan Kota Tegal. Jurnal Kesehatan Masyarakat (e-Journal). 2020;8(3):432-9.

9. Hida Fitri M. M. Pelatihan Terhadap Keterampilan Kader Posyandu. Jurnal Kesehatan Masyarakat. 2011;7(1):22-7.

10. Aisyaroh, N., Susiloningtyas, I. \& Mubarok. Pengembangan Intervensi MP-ASI dengan Metode Demonstrasi pada Kader Posyandu Di Desa Batur Kecamatan Getasan Kabupaten Semarang. Prosiding Implementasi Penelitian Pada Pengabdian Menuju Masyarakat Mandiri Berkemajuan. 2017;

11. Astuti NR. Promosi Kesehatan Gigi dan Mulut dengan Metode Ceramah Interaktif dan Demonstrasi Disertai AlatPeraga pada Guru Sekolah Dasar Sebagai Fasilitator. International Dental Journal. 2013;16-25.

12. Notoatmodjo S. promosi kesehatan dan perilaku kesehatan (edisi revisi 2012). Jakarta: rineka cipta. 2012;

13. Priyoto. Teori sikap dan perilaku dalam kesehatan: dilengkapi contoh kuesioner / Priyoto. In: ISBN: 978-602-1547-53-3. 2014.

14. Salakory JA. Pengaruh Pelatihan Terhadap Pengetahuan, Sikap, Dan Praktik Kader Tentang Penyuluhan Pencegahan Hiv/Aids Di Puskesmas Hative Kecil. Journal of Chemical Information and Modeling. 2019;53(9):168999 